\title{
The role of glucocorticoid in the regulation of prostaglandin biosynthesis in non-pregnant bovine endometrium
}

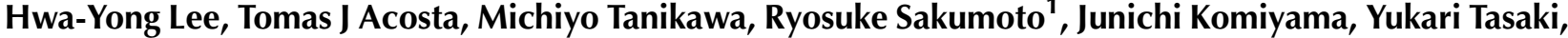 \\ Mariusz Piskula², Dariusz J Skarzynski ${ }^{3}$, Masafumi Tetsuka ${ }^{4}$ and Kiyoshi Okuda \\ Laboratory of Reproductive Endocrinology, Graduate School of Natural Science and Technology, Okayama University, Okayama 700-8530, Japan \\ ${ }^{1}$ Department of Physiology and Genetic Regulation, National Institute of Agrobiological Sciences, Ibaraki 305-0901, Japan \\ Departments of ${ }^{2}$ Food Technology and ${ }^{3}$ Reproductive Immunology, Institute of Animal Reproduction and Food Research, Polish Academy of Sciences, Olsztyn \\ 10-747, Poland \\ ${ }^{4}$ Department of Agricultural and Life Science, Obihiro University of Agriculture and Veterinary Medicine, Obihiro, Hokkaido 080-8555, Japan \\ (Requests for offprints should be addressed to K Okuda; Email: kokuda@cc.okayama-u.ac.jp)
}

\begin{abstract}
To determine whether glucocorticoids (GCs) play a role in regulating uterine function in cow, the present study examined the expression of mRNA encoding GC receptor (GC-R) $\alpha, 11 \beta$-hydroxysteroid dehydrogenase (11-HSD) type 1 and type 2, and the activity of 11-HSD1 in bovine endometrial tissue throughout the estrous cycle. We also studied the effects of cortisol on basal, oxytocin (OT)- and tumor necrosis factor- $\alpha$ (TNF $\alpha)$-stimulated prostaglandin (PG) production. A quantitative real-time PCR analysis revealed that GC-R $\alpha$ mRNA was expressed more strongly in the mid-luteal stage (days 8-12) than in the other stages. In contrast to GC-R $\alpha$ mRNA expression, 11-HSD1 mRNA expression was greater in the follicular stage than in the other stages, whereas 11-HSD2 mRNA expression was lowest in the follicular stage. The activity of 11-HSD1 was greater in
\end{abstract}

the follicular stage and estrus than in the other stages and was lowest in the mid-luteal stage. Cortisone was dosedependently converted to cortisol in the cultured endometrial tissue. Although cortisol did not affect either the basal or OT-stimulated production of PGs in the cultured epithelial cells, the production of PGs stimulated by TNF $\alpha$ in the stromal cells was suppressed by cortisol $(P<0 \cdot 05)$. Cortisol suppressed basal prostaglandin (PG)F $2 \alpha$ without affecting basal PGE2 production in the stromal cells. The overall results suggest that the level of cortisol is locally regulated in bovine endometrium throughout the estrous cycle by 11-HSD1, and that cortisol could act as a luteoprotective factor by selectively suppressing luteolytic PGF2 $\alpha$ production in bovine endometrium.

Journal of Endocrinology (2007) 193, 127-135

\section{Introduction}

Glucocorticoids (GCs) are involved in various physiological processes, including general metabolism (Wang 2005), immunological response (McKay \& Cidlowski 1998, 1999), and female reproductive function (Brann \& Mahesh 1991, Andersen 2002). At high concentrations, GCs suppress most immunological responses and are well known as antiinflammatory agents limiting the production of cytokines and prostaglandins (PGs) in various target organs (GoppeltStruebe et al. 1996, Goppelt-Struebe 1997, Hillier \& Tetsuka 1998). Several uterine events such as menstruation, implantation, and parturition have been likened to an inflammatory process (Salamonsen \& Lathbury 2000). Because GCs have been shown to exert specific effects on uterine physiology in rats (Rabin et al. 1990, Korgun et al. 2003), rabbits (Bigsby \& Everett 1991), humans (Gellersen et al. 1994), and ewes (Monheit \& Resnik 1981, Gupta et al. 2003), the uterus is considered to be a target organ for GCs in some species. However, the roles of GCs in the bovine endometrium remain unknown.

The endometrium is a complex tissue and mainly consists of epithelial and stromal cells (Fortier et al. 1988). Although both types of endometrial cells have the capacity to produce PGs, they have specific morphological and physiological properties (Asselin et al. 1997, Fortier et al. 1988, Miyamoto et al. 2000). We found that oxytocin (OT) stimulates PG production only in epithelial cells, while tumor necrosis factor- $\alpha$ (TNF $\alpha)$ stimulates PG production only in stromal cells (Skarzynski et al. 2000). This cell-specific response to OT and TNF $\alpha$ is a useful parameter for investigating the physiology and endocrine status of cultured bovine endometrial cells.

The biological action of GCs is mediated through the activation of intracellular GC receptors (GC-R). Two isoforms of GC-R, GC-R $\alpha$ and GC-R $\beta$, have been identified (Giguere 
et al. 1986, Funder 1993). Access of GCs to GC-R in target tissues is regulated by two $11 \beta$-hydroxysteroid dehydrogenases (11-HSDs), a bidirectional 11-HSD type 1 (11-HSD1) that mainly converts cortisone to active cortisol (Stewart \& Mason 1995) and 11-HSD type 2 (11-HSD2) that inactivates cortisol to cortisone (Albiston et al. 1994, Stewart et al. 1994). Therefore, cyclic changes of the expressions of GC-R and 11-HSDs mRNA could help to define the roles of GCs in uterine physiology.

In the present study, to determine whether GCs play a role in regulating bovine uterine function, we examined 1) the temporal patterns of GC-R $\alpha, 11-\mathrm{HSD} 1$, and 11-HSD2 mRNA expressions, and 11-HSD1 activity in bovine endometrium throughout the estrous cycle and 2) the effects of cortisol on basal and OT- or TNF $\alpha$-stimulated PG production in the cultured endometrial epithelial and stromal cells.

\section{Materials and methods}

\section{Collection of endometrial tissues}

Uteri of Holstein cows were obtained from a local abattoir in accordance with protocols approved by the local Institutional Animal Care and Use Committee. Apparently, healthy uteri without a visible conceptus were obtained within 10-20 min after exsanguination and immediately transported to the laboratory on ice. The stages of the estrous cycle were determined by macroscopic observation of the ovary and uterus as described previously (Okuda et al. 1988, Miyamoto et al. 2000). For mRNA determination, endometrial tissues ( $n=8 /$ stage) were collected from cows at six different stages of the estrous cycle (estrus, day 0; early luteal, days 2-3; developing luteal, days 5-6; mid-luteal, days 8-12; late luteal, days 15-17, and follicular stage, days 19-21). Intercaruncular endometrial tissues from the uterine horn, ipsilateral to the corpus luteum, were used for all experiments. The endometrial tissues were immediately frozen rapidly in liquid nitrogen and stored at $-80{ }^{\circ} \mathrm{C}$ until processed for RNA isolation. For experiments involving tissue and cell cultures, the uterus was submerged in ice-cold physiological saline and transported to the laboratory.
Experiment 1: determination of $G C-R \alpha, 11-H S D s m R N A$ expressions and 11-HSD1 activity throughout the estrous cycle

Reverse transcription and real-time PCR Total RNA was extracted from endometrial tissue using TRIZOL reagent (Invitrogen) according to the manufacturer's directions. One microgram of each total RNA was reverse transcribed using a ThermoScript RT-PCR System (Invitrogen) and $10 \%$ of the reaction mixture was used in each PCR using specific primers for GC-R $\alpha$ and 11-HSDs from the bovine sequence. The primers were chosen using an online software package (http://www-genome.wi.mit.edu/ cgi-bin/primer/primer3_www.cgi).

Gene expression was measured by real-time PCR using the Mx3000P QPCR System (Stratagene, La Jolla, CA, USA) and the QuantiTect SYBR Green PCR system (Qiagen) starting with $2 \mathrm{ng}$ reverse-transcribed total RNA as described previously (Sakumoto et al. 2005; Table 1). Briefly, GAPDH expression was used as an internal control. For quantification of the mRNA expression levels, the primer length $(20 \mathrm{bp})$ and GC contents of each primer (50-60\%) were selected, and PCR was performed under the following conditions: $95^{\circ} \mathrm{C}$ for $15 \mathrm{~min}$, followed by 55 cycles of $94{ }^{\circ} \mathrm{C}$ for $15 \mathrm{~s}, 55^{\circ} \mathrm{C}$ for $20 \mathrm{~s}$, and $72{ }^{\circ} \mathrm{C}$ for $15 \mathrm{~s}$. Use of the QuantiTect SYBR Green PCR system at elevated temperatures resulted in reliable and sensitive quantification of the RT-PCR products with high linearity (Pearson's correlation coefficient $(r>0 \cdot 99))$.

11-HSD1 activity The level of 11-HSD reductase activity in endometrial tissue was determined by measuring the net conversion rate from cortisone to cortisol. Briefly, endometrial strips $(30 \mathrm{mg})$ were placed in glass culture tubes $(12 \mathrm{~mm} \times 75 \mathrm{~mm})$ containing $2 \mathrm{ml}$ culture medium (Dulbecco's modified Eagle's medium (DMEM)/Ham's F-12; 1:1 (v/v); Sigma) supplemented with $0 \cdot 1 \%(\mathrm{w} / \mathrm{v})$ BSA, $100 \mathrm{IU} / \mathrm{ml}$ penicillin, and $100 \mu \mathrm{g} / \mathrm{ml}$ streptomycin with $5 \% \mathrm{CO}_{2}$ in air. The endometrial tissues were exposed to cortisone $(0,3,30,300$, and $1000 \mathrm{nM})$ in a shaking water bath at $38{ }^{\circ} \mathrm{C}$ for $4 \mathrm{~h}$. Media containing cortisone $(0,3,30,300$, and $1000 \mathrm{nM}$ ) without tissues were incubated for $4 \mathrm{~h}$ for the blank value and to determine non-specific interconversion. At the end of incubation, $1 \mathrm{ml}$ conditioned medium was

Table 1 Primers for real-time PCR

\begin{tabular}{|c|c|c|c|c|}
\hline & Primer & Sequence & Accession no. & Product $(\mathrm{bp})$ \\
\hline \multicolumn{5}{|l|}{ Gene } \\
\hline \multirow[t]{2}{*}{$G C-R \alpha$} & Forward & 5'-CCATTTCTGTTCACGGTGTG-3' & AY238475 & 132 \\
\hline & Reverse & 5'-CTGAACCGACAGGAATTGGT-3' & & \\
\hline \multirow[t]{2}{*}{ 11-HSD1 } & Forward & 5'-ACTCTGCGCCAAGATGAAGT-3' & AF548027 & 149 \\
\hline & Reverse & 5'-TAGCCCTCAGGAAGTGCCTA-3' & & \\
\hline \multirow[t]{2}{*}{ 11-HSD2 } & Forward & $5^{\prime}$-CCTAGACCGGATCCTTCTCC-3' & AF074706 & 114 \\
\hline & Reverse & $5^{\prime}$-ACCTTGGGGGTCAGAATACC-3' & & \\
\hline \multirow[t]{2}{*}{ GAPDH } & Forward & 5'-CACCCTCAAGATTGTCAGCA-3' & BC102589 & 103 \\
\hline & Reverse & 5'-GGTCATAAGTCCCTCCACGA-3' & & \\
\hline
\end{tabular}


collected and frozen at $-30{ }^{\circ} \mathrm{C}$ until the cortisol assay. The tissues were blotted on filter paper and weighed. The specific conversion rate from cortisone to cortisol was calculated, and the blank values (defined as the amount of conversion in the absence of tissue) were subtracted and expressed as picogram of cortisol converted per milligram of tissue ( $\mathrm{pg} / \mathrm{mg}$ tissue). To examine the cyclic changes in 11-HSD1 activity throughout the estrous cycle, the endometrial tissues from the estrus, early luteal, developing luteal, mid-luteal, late luteal, and follicular stages $(n=4 /$ stage $)$ were exposed to cortisone (30 nM).

Isolation of endometrial cells For cell culture, endometrial tissues were obtained at the early luteal phase (days $2-5$ ). The epithelial and stromal cells from the bovine endometrium were separated using a modification of procedures described previously (Skarzynski et al. 2000). A polyvinyl catheter was inserted into the side of the oviduct and the ends of the horn were tied in order to retain trypsin solution for detaching the epithelial cells as described below. The uterine lumen was washed thrice with $30-50 \mathrm{ml}$ sterile $\mathrm{Ca}^{2+}$ - and $\mathrm{Mg}^{2+}$-free Hanks' balanced salt solution (HBSS) supplemented with $100 \mathrm{IU} / \mathrm{ml}$ penicillin, $100 \mu \mathrm{g} / \mathrm{ml}$ streptomycin, and $0 \cdot 1 \%$ (w/v) BSA (Roche Diagnostics). Thirty to fifty milliliters of sterile HBSS containing $0.3 \%(\mathrm{w} / \mathrm{v})$ trypsin (Sigma) was then infused into the uterine lumen through the catheter. Epithelial cells were isolated by incubation at $38^{\circ} \mathrm{C}$ for $60 \mathrm{~min}$ with gentle shaking.

After collection of the epithelial cells, the uterine lumen was washed with sterile HBSS supplemented with antibiotics and $0 \cdot 1 \%(\mathrm{w} / \mathrm{v})$ BSA. The horn was then cut transversely with scissors into several segments, which were slit to expose the endometrial surface. Intercaruncular endometrial strips were dissected from the myometrial layer with a scalpel and washed once in $50 \mathrm{ml}$ sterile HBSS containing antibiotics. The endometrial strips were then minced into small pieces $\left(1 \mathrm{~mm}^{3}\right)$. The minced tissues $(\approx 5 \mathrm{~g})$ were digested by stirring for $60 \mathrm{~min}$ in $50 \mathrm{ml}$ sterile HBSS containing $0.05 \%(\mathrm{w} / \mathrm{v}$ ) collagenase (Sigma), 0.005\% (w/v) DNase I (Sigma) and 0.1\% $(\mathrm{w} / \mathrm{v})$ BSA. The dissociated cells were filtered through metal meshes $(100$ and $80 \mu \mathrm{m})$ to remove undissociated tissue fragments. The filtrate was washed thrice by centrifugation (10 min at $100 \boldsymbol{g}$ ) with DMEM (Sigma) supplemented with antibiotics and $0 \cdot 1 \%(\mathrm{w} / \mathrm{v})$ BSA. After the washes, the cells were counted with a hemocytometer. Cell viability was higher than $85 \%$ as assessed by $0.5 \%(\mathrm{w} / \mathrm{v})$ trypan blue dye exclusion.

Culture of endometrial cells The final pellets of the isolated stromal or epithelial cells were resuspended in culture medium (DMEM/Ham's F-12; 1:1 (v/v); Sigma) supplemented with $10 \%(\mathrm{v} / \mathrm{v})$ calf serum (Sigma), $20 \mu \mathrm{g} / \mathrm{ml}$ gentamicin (Invitrogen), and $2 \mu \mathrm{g} / \mathrm{ml}$ amphotericin B (Sigma; Skarzynski et al. 2000). The stromal cells were seeded at a density of $1 \times 10^{5}$ viable cells $/ \mathrm{ml}$ in 48 -well cluster dishes (Costar, Cambridge, MA, USA), and the epithelial cells were seeded at a density of $1 \times 10^{5}$ viable cells $/ \mathrm{ml}$ in culture flasks (Nunc) and cultured at $38^{\circ} \mathrm{C}$ in a humidified atmosphere of $5 \% \mathrm{CO}_{2}$ in air. To purify the stromal preparation, the medium was changed $2 \mathrm{~h}$ after plating, by which time selective attachment of stromal cells had occurred (Fortier et al. 1988, Skarzynski et al. 2000). Alternatively, since the epithelial cells attached $24-48 \mathrm{~h}$ after plating, the medium in the epithelial cell culture was replaced $48 \mathrm{~h}$ after plating. The medium was changed every 2 days until the cells reached confluence. When the epithelial cells were confluent, $0 \cdot 02 \%(\mathrm{w} / \mathrm{v})$ trypsin solution was added to the cells to remove the other cells. After removal of the other cells, $0 \cdot 25 \%(\mathrm{w} / \mathrm{v})$ trypsin solution was then added to the epithelial cells to collect the pure epithelial cells. The cells were removed, adjusted to a density of $1 \times$ $10^{5}$ cells $/ \mathrm{ml}$, and placed in 48-well cluster dishes for DNA quantification in fresh DMEM/Ham's F-12 supplemented with $10 \%(\mathrm{v} / \mathrm{v})$ calf serum, $20 \mu \mathrm{g} / \mathrm{ml}$ gentamicin, and $2 \mathrm{mg} / \mathrm{ml}$ amphotericin B until the cells reached confluence. The homogeneity of stromal and epithelial cells was evaluated using immunofluorescent staining for specific markers of epithelial (cytokeratin) and stromal cells (vimentin; Murakami et al. 2003) as described previously. The epithelial cell contamination of stromal cells was about $1 \%$ and stromal cell contamination of epithelial cells was $<1 \%$. When cells of each type were confluent (6-7 days after the start of the culture), the medium was replaced with fresh DMEM/Ham's F-12 supplemented with $0 \cdot 1 \%(\mathrm{w} / \mathrm{v})$ BSA, $5 \mathrm{ng} / \mathrm{ml}$ sodium selenite (Sigma), $0.5 \mathrm{mM}$ ascorbic acid (Wako Pure Chemical Industries, Ltd, Osaka, Japan), $5 \mu \mathrm{g} / \mathrm{ml}$ transferrin (Sigma), $2 \mu \mathrm{g} / \mathrm{ml}$ insulin (Sigma), and $20 \mu \mathrm{g} / \mathrm{ml}$ gentamicin. The cells were then exposed to various stimulants for Experiment 2.

Experiment 2: effect of cortisol on basal and OT- or TNF $\alpha$ stimulated PGF2 $\alpha$ and PGE2 production by epithelial and stromal cells

Epithelial cells were exposed to cortisol $(0 \cdot 1-100 \mathrm{nM})$, OT (100 nM; Teikoku Hormone MFG Co., Tokyo, Japan), or cortisol in combination with OT for $24 \mathrm{~h}$. Stromal cells were exposed to cortisol $(0 \cdot 1-100 \mathrm{nM})$, TNF $\alpha \quad(0.06 \mathrm{nM}$; Dainippon Pharmaceutical Co., Ltd, Osaka, Japan), or cortisol in combination with TNF $\alpha$ for $24 \mathrm{~h}$. The concentrations of OT and TNF $\alpha$ were based on a previous study (Skarzynski et al. 2000). Media with supplements without stimulants incubated with cells were used as controls.

After culture, the conditioned media were collected in $1.5 \mathrm{ml}$ tubes containing $5 \mu \mathrm{l}$ of a stabilizer solution $(0.3 \mathrm{M}$ EDTA, 1\% (w/v) acid acetyl salicylic, $\mathrm{pH} 7 \cdot 3)$ and frozen at $-30{ }^{\circ} \mathrm{C}$ until the PGs assay. The DNA content, estimated by the spectrophotometric method of Labarca \& Paigen (1980), was used to standardize the results.

PG and cortisol determination The concentrations of PGF $2 \alpha$ and PGE2 in the culture medium were determined by enzyme immunoassay (EIA) as described previously (Woclawek-Potocka et al. 2004). The PGF2 $\alpha$ standard 
curve ranged from $0 \cdot 016$ to $4 \mathrm{ng} / \mathrm{ml}$ and the ED50 of the assay was $0.25 \mathrm{ng} / \mathrm{ml}$. The intra- and inter-assay coefficients of variation were on average $2 \cdot 8$ and $7 \cdot 7 \%$ respectively. The PGE2 standard curve ranged from 0.39 to $100 \mathrm{ng} / \mathrm{ml}$ and the ED50 of the assay was $6 \cdot 25 \mathrm{ng} / \mathrm{ml}$. The intra- and inter-assay coefficients of variation were on average $3 \cdot 1$ and $8 \cdot 6 \%$ respectively. The EIA for cortisol was done as described previously (Acosta et al. 2002). The standard curve ranged from $0 \cdot 1$ to $400 \mathrm{ng} / \mathrm{ml}$ and the ED50 of the assay was $1.6 \mathrm{ng} / \mathrm{ml}$. The intra- and inter-assay coefficients of variation were on average 5.4 and $6.0 \%$ respectively. The cross-reactivities of the polyclonal antibody (raised in a rabbit against cortisol-3-carboxymethyloxime (CMO); Cosmo Bio Co., Tokyo, Japan) were 100\% for cortisol, $0 \cdot 6 \%$ for cortisone, $5 \cdot 7 \%$ for 11 -deoxycortisol, $0 \cdot 5 \%$ for 21-deoxycortisol, $4 \cdot 1 \%$ for 11 -deoxycorticosterone, $1 \cdot 2 \%$ for corticosterone, $0 \cdot 7 \%$ for $17 \boldsymbol{\alpha}$-hydroxy progesterone, and $0 \cdot 02 \%$ for 20-dihydroxy progesterone.

\section{Statistical analysis}

Experimental data are shown as the mean \pm s.E.M. of values obtained in four to five separate experiments, each performed in triplicate. Endometrial cells and tissues collected from different cows were cultured separately. Data on the effects of cortisol, TNF $\alpha$, and OT on absolute concentrations of PGF2 $\alpha$ and PGE2 were statistically analyzed and are shown as a fold change of the control. The statistical significance of differences in concentrations of PG in culture media between the control and treated groups and the mRNA expressions was assessed by one-way ANOVA followed by Fisher's protected least-significant difference procedure (PLSD) as a multiple comparison test by StatView (Version 4.58; Abacus Concepts, Inc. Berkeley, CA, USA).

\section{Results}

$m R N A s$ for GC-R $\alpha, 11-H S D 1$, and 11-HSD2 during the estrous cycle

Specific transcripts for GC-R $\alpha, 11-\mathrm{HSD} 1$, and 11-HSD2 were detected in bovine endometrium throughout the estrous cycle. A real-time PCR analysis of $\mathrm{GC}-\mathrm{R} \alpha$, 11-HSD1, and 11-HSD2 mRNA in the endometrial tissue during the estrous cycle is shown in Fig. 1. The level of mRNA for GC-R $\alpha$ was greater in the mid-luteal stage (days $8-12$ ) than in the other stages (Fig. 1A; $P<0 \cdot 05$ ). In contrast, the level of mRNA for 11-HSD1 was greater in the follicular stage than in the other stages (Fig. 1B; $P<0 \cdot 05$ ), whereas the level of mRNA for 11-HSD2 was lowest in the follicular stage (Fig. 1C; $P<0 \cdot 05$ ).

\section{1-HSD1 activity throughout the estrous cycle}

Endometrial tissue has the capacity to convert cortisone to cortisol as indicated by a significant increase in cortisol
A

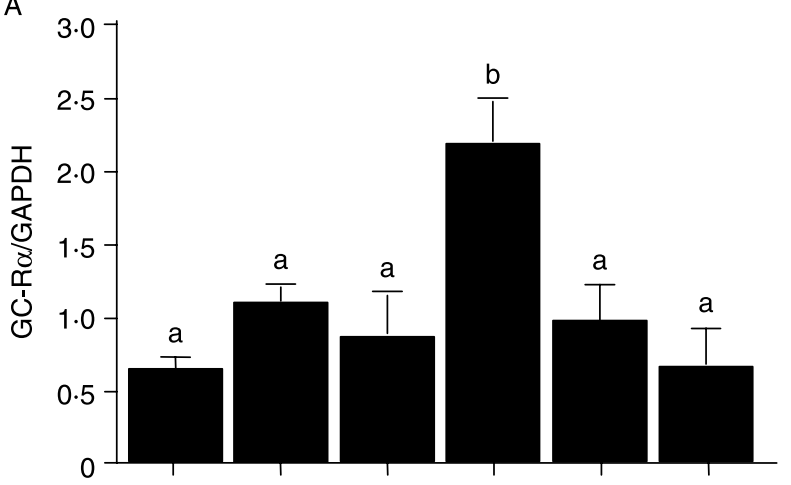

B

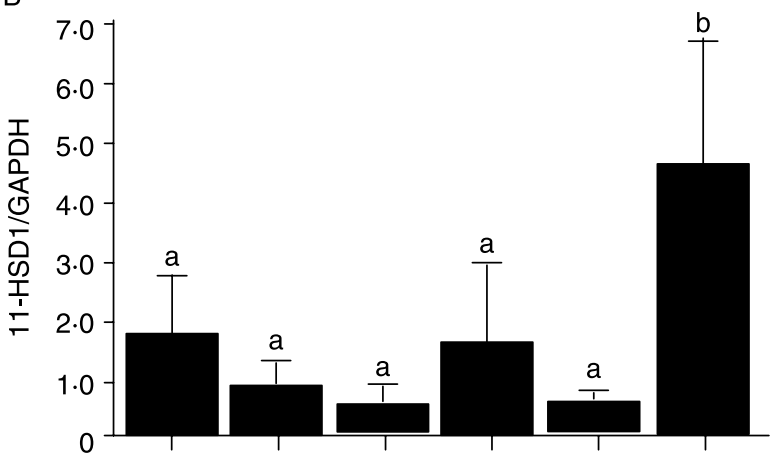

C

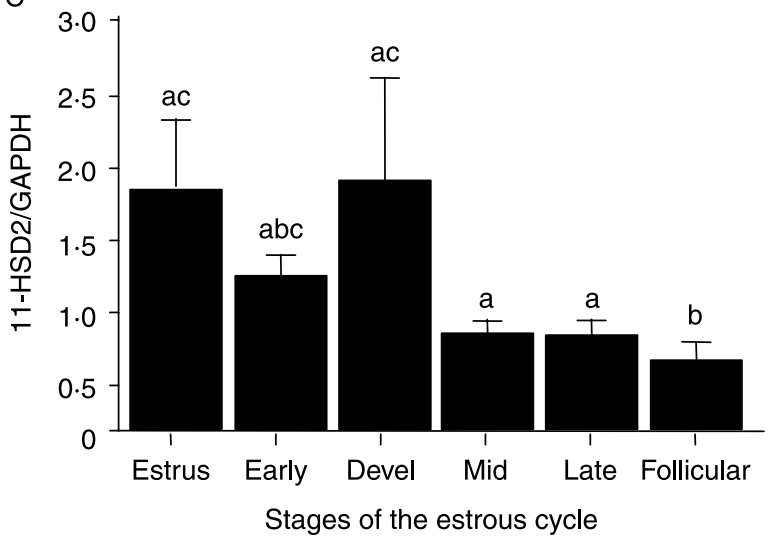

Figure 1 Changes in relative amounts of (A) GC-R $\alpha$, (B) 11-HSD1, and (C) 11-HSD2 mRNA in bovine endometrium throughout the estrous cycle. Data are the mean \pm s.E.M. for eight samples/stage and are expressed as the relative ratio of GC-R $\alpha$ and 11-HSDs mRNA to GAPDH mRNA (estrus, day 0; early luteal, days 2-3; developing luteal, days 5-6; mid-luteal, days 8-12; late luteal, days 15-17; and follicular stage, days 19-21). Different superscript letters indicate significant difference $(P<0 \cdot 05)$, as determined by ANOVA followed by a Fisher's PLSD as a multiple comparison test.

content in the medium incubated with tissue compared with those incubated without tissue. The concentration of converted cortisol in the media increased with the dose of cortisone (Fig. 2A). The activity of 11-HSD1 was lowest in the mid-luteal stage and greater in the follicular stage and estrus than in the other stages (Fig. 2B). It was shown that 

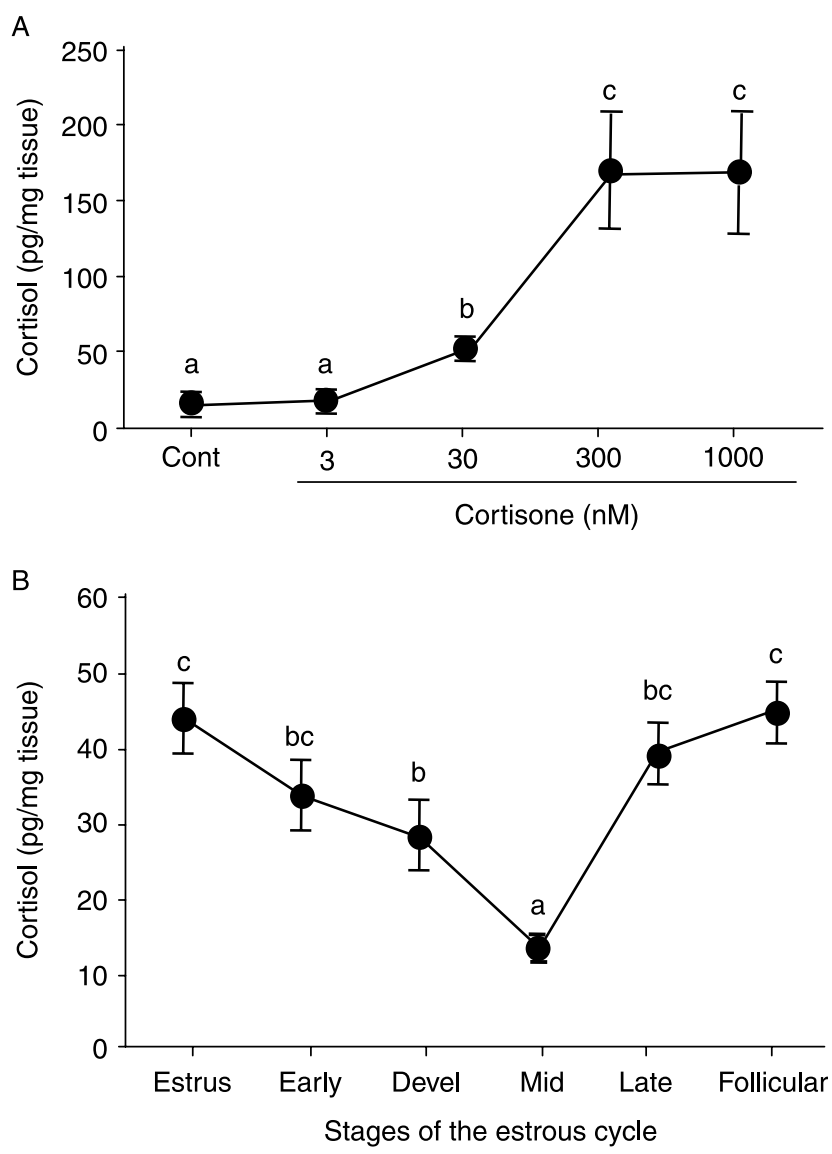

Figure 2 (A) Dose-dependent effects of cortisone on 11-HSD1 activity by endometrial tissue from the follicular stage. (B) Endometrial tissues were exposed to cortisone (0-1000 nM) for $4 \mathrm{~h}$. Changes in 11-HSD1 activity in endometrial tissue throughout the estrous cycle (mean \pm s.E.M., $n=4 /$ stage). 11 -HSD1 activity was determined using cortisone as substrate; endometrial tissues (30 mg) were exposed to cortisone $(30 \mathrm{nM})$ for $4 \mathrm{~h}$. Different superscript letters indicate significant difference $(P<0 \cdot 05)$, as determined by ANOVA followed by a Fisher's PLSD as a multiple comparison test.

maximal cortisol concentration was reached at a cortisone concentration of $300 \mathrm{nM}$.

Effect of cortisol on basal and OT-stimulated PGs production in epithelial cells

Oxytocin significantly increased both PGF2 $\alpha$ and PGE2 production $(P<0 \cdot 05)$ compared with the basal level. Cortisol $(0 \cdot 1-100 \mathrm{nM})$ did not affect basal or OT-stimulated production of PGF2 $\alpha$ or PGE2 by epithelial cells (Fig. 3A and B).

\section{Effect of cortisol on basal and TNF $\alpha$-stimulated PGs production in stromal cells}

Cortisol decreased basal production of PGF $2 \alpha$ from stromal cells at concentrations of 10 and $100 \mathrm{nM}$, but did not affect
PGE2 production (Fig. 4A and B). TNF $\alpha$ stimulated both PGF2 $\alpha$ and PGE2 production $(P<0 \cdot 05)$. The production of TNF $\alpha$-stimulated PGF2 $\alpha$ and PGE2 was inhibited by cortisol in a dose-dependent manner.

\section{Discussion}

The present study demonstrated for the first time the temporal pattern of GC-R $\alpha, 11-\mathrm{HSD} 1$, and 11-HSD2 mRNA expression in the bovine endometrium throughout the estrous cycle. In addition, cortisol inhibited basal and TNF $\alpha$-stimulated PGF2 $\alpha$ production without affecting basal PGE2 production in the cultured stromal cells, whereas it did not affect basal or OT-stimulated PG output in the epithelial cells. These findings suggest that GCs play a role in regulating PG production in bovine endometrial stromal cells.

Cortisol, mainly synthesized in the adrenal cortex, reaches the target organs in one of two forms. The majority is bound to plasma proteins and only a small fraction is free and unbound. The steroid-binding proteins reduce alterations in the levels of biologically active free cortisol, maintaining its level relatively constant (Munck et al. 1984, Escher et al. 1997). The biological activity of cortisol seems to be confined to the free unbound fraction, which is available for movement out of capillaries and into cells, where it may initiate a biological response (Hryb et al. 1990). The biological action of GC is mediated through intracellular GC-R. Two isoforms of GC-R (GC-R $\alpha$ and GC-R $\beta$ ), which originate from the same gene by alternative splicing of the GC-R primary transcript, have been identified (Hollenberg et al. 1985, Encio \& Detera-Wadleigh 1991, Oakley et al. 1996). Since the ligand-dependent GC-R $\alpha$ stimulates gene transcription in GC target tissues, GC-R $\alpha$ is thought to be the active receptor isoform (Hollenberg et al. 1985). The levels of GC-R $\alpha$ mRNA data obtained in the present study were inversely correlated with the levels of PGF $2 \alpha$ output by bovine endometrial tissue that we found in our previous studies (Miyamoto et al. 2000, Murakami et al. 2001). Plasma concentrations of cortisol are low during the luteal phase (days 7-16; McCann \& Hansel 1986). Therefore, the differential expression of GC-R $\alpha$ during the estrous cycle may be important for GC actions controlling endometrial PG production. Since cortisol inhibited basal and TNF $\alpha-$ stimulated PGF $2 \alpha$ production in the stromal cells in the present study, an increase of GC-R $\alpha$ may be responsible for the low endometrial PGF $2 \alpha$ production during the midluteal phase. Cortisol may down-regulate its own receptor to prevent an exaggerated response to cortisol, when cortisol is abundant in the stromal cells. It is also possible that the low PG production in the mid-luteal phase is due to other mechanisms, such as the down-regulation of oxytocin receptor by progesterone, the availability of arachidonic acid, or a decrease in the expression or activity of PGHS. Since PGF $2 \alpha$ is synthesized from PGE2 by 9K-PGR, or from PGD2 or PGH2 by PGFS (Asselin \& Fortier 2000, 

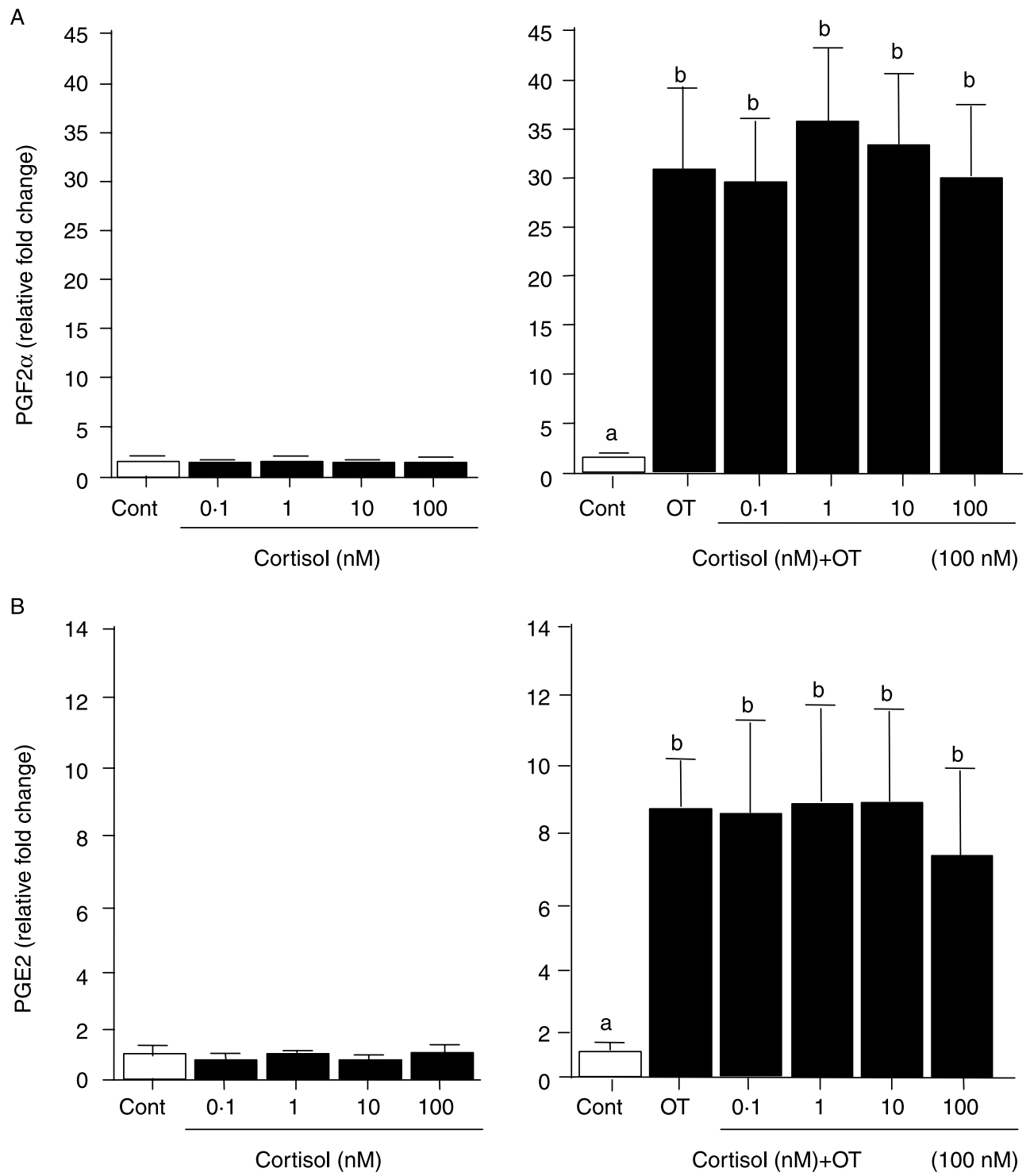

Figure 3 Effects of cortisol on basal or OT-stimulated (A) PGF2 $\alpha$ and (B) PGE2 production by cultured bovine epithelial cells (mean \pm s.E.M., $n=5$ experiments). Cortisol $(0 \cdot 1-100 \mathrm{nM})$ with or without OT (100 nM) was added $24 \mathrm{~h}$ before the end of culture. The concentrations of PGF2 $\alpha$ and PGE2 in untreated controls were used to calculate the baseline. All values are expressed as the mean fold change of a percentage of the baseline. The concentrations of PGF2 $\alpha$ and PGE2 in the control were $27 \cdot 54 \pm 9 \cdot 34 \mathrm{pg} / \mu \mathrm{g}$ DNA and $1 \cdot 03 \pm 0 \cdot 54 \mathrm{ng} / \mu \mathrm{g}$ DNA in epithelial cells respectively. Different superscript letters indicate significant difference $(P<0 \cdot 05)$, as determined by ANOVA followed by a Fisher's PLSD as a multiple comparison test. Cont, control.

Madore et al. 2003), GC may also decrease the expression or activity of the enzymes in bovine endometrium. Further studies on mRNA, protein expressions or activities of the above enzymes are necessary.

In the present study, the profile of 11-HSD1 mRNA expression during the estrous cycle contrasted with that of 11-HSD2. 11-HSD1 mRNA remained low during the estrus, early, developing, mid-, and late luteal phases, and markedly increased in the follicular phase, whereas the expression of 11-HSD2 mRNA was at the lowest level in the follicular phase. The change in 11-HSD1 activity in bovine endometrial tissue throughout the estrous cycle has not been previously reported. The increase in 11-HSD1 mRNA was temporally coincident with the increase in the basal release of PGF2 $\alpha$ during the estrous cycle (Miyamoto et al. 2000, Murakami et al. 2001). PGF2 $\alpha$ has been demonstrated to stimulate 11-HSD1 activity in human chorionic trophoblasts to generate biologically active cortisol (Alfaidy et al. 2001). Therefore, it is possible that the increased PGF2 $\alpha$ production by the endometrium in the late luteal and 
A
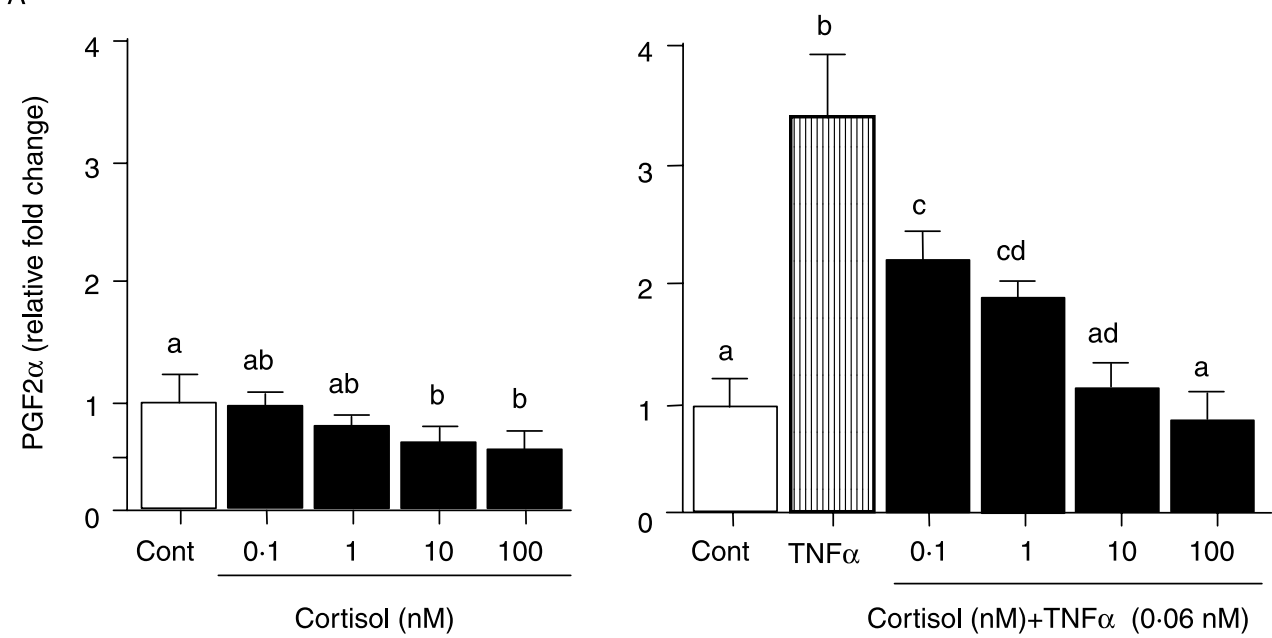

B
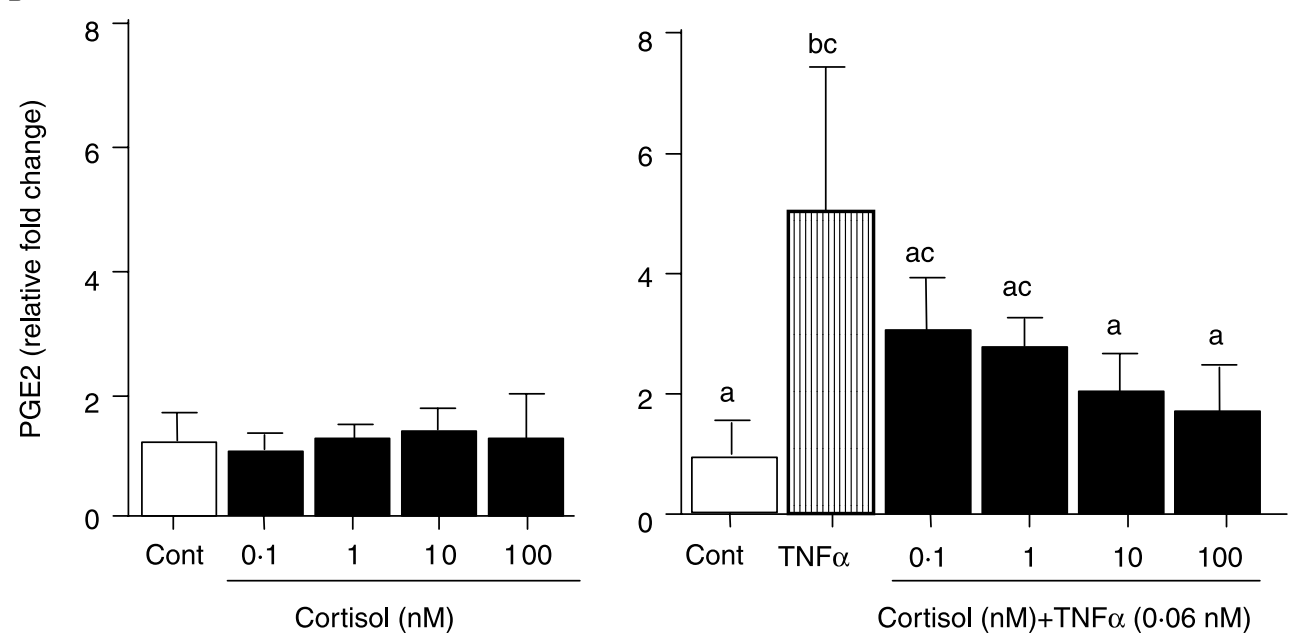

Figure 4 Effects of cortisol on basal or TNF $\alpha$-stimulated (A) PGF2 $\alpha$ and (B) PGE2 production by cultured bovine stromal cells (mean \pm S.E.M., $n=5$ experiments). Cortisol $(0 \cdot 01-100 \mathrm{nM})$ with or without TNF $\alpha$ $(0 \cdot 06 \mathrm{nM})$ was added $24 \mathrm{~h}$ before the end of culture. The concentrations of PGF2 $\alpha$ and PGE2 in untreated controls were used to calculate the baseline. All values are expressed as a percentage of the baseline. The concentrations of PGF2 $\alpha$ and PGE2 in the control were $77 \cdot 71 \pm 19 \cdot 09 \mathrm{pg} / \mu \mathrm{g}$ DNA and $3 \cdot 48 \pm 1 \cdot 36 \mathrm{ng} / \mu \mathrm{g}$ DNA in stromal cells respectively. Different superscript letters indicate significant difference $(P<0 \cdot 05)$, as determined by ANOVA followed by a Fisher's PLSD as a multiple comparison test. Cont, control.

the follicular stages stimulates 11-HSD1 activity. The increased 11-HSD1 activity may then enhance the conversion of cortisone to cortisol in the bovine endometrium to reduce PGF2 $\alpha$ production in the following stage of the estrous cycle. In fact, the PGF $2 \alpha$ concentration in the ovarian-uterine venous plasma is high before the luteinizing hormone (LH) surge and drops as the LH surge approaches (Acosta et al. 2000). The decrease in PGF2 $\alpha$ concentration in the follicular phase observed in our previous studies (Miyamoto et al. 2000, Murakami et al. 2001) was temporally associated with the highest 11-HSD1 mRNA expression and activity in the follicular stage. Thus, cortisol may play a physiologically relevant role in preventing excessive uterine PG production during the follicular phase. Furthermore, 11-HSD1 and 11-HSD2 may be directly involved in the cyclic changes in cortisol action to control endometrial PG production. However, since the cellular levels of enzyme cofactors such as NADP + and NADPH have also been demonstrated to influence the activities of 11-HSDs (Michael et al. 2003), conversion of cortisone to cortisol in the present study may be influenced by the levels of enzyme cofactors such as NADP + and NADPH in the bovine endometrium. Further studies are needed to clarify the role of NADP + and NADPH during the estrous cycle.

In ruminants, PGF2 $\alpha$ originating from the endometrium is responsible for luteolysis (McCracken et al. 1999), whereas 
PGE2 is thought to exert actions opposite to those of PGF2 $\alpha$, i.e. luteoprotective actions, for establishing pregnancy (Pratt et al. 1977, Magness et al. 1981). Furthermore, TNF $\alpha$ has been demonstrated to affect the length of the estrous cycle through controlling uterine $\mathrm{PG}$ production in the cow (Skarzynski et al. 2003). A 30-min infusion of $1 \mu \mathrm{g}$ TNF $\alpha$ into the posterior aorta abdominalis on day 14 induced luteolysis and shortened the estrous cycle in cattle (Skarzynski et al. 2003), whereas $10 \mu \mathrm{g}$ TNF $\alpha$ extended the estrous cycle. The changes in the length of the estrous cycle may have resulted from a preferential stimulation of PGF2 $\alpha$ by a low dose of TNF $\alpha$ and a preferential stimulation of PGE2 by a high dose of TNF $\alpha$. In the present study, cortisol inhibited TNF $\alpha$-stimulated PGE2 and PGF $2 \alpha$ production in a dosedependent manner. In addition, cortisol inhibited basal PGF2 $\alpha$, whereas it did not affect basal PGE2 production in the stromal cells. These findings strongly suggest that cortisol mainly acts as an antiluteolytic factor suppressing basal and TNF $\alpha$-stimulated PGF $2 \alpha$ production in bovine endometrial stromal cells. Furthermore, the fact that cortisol did not affect basal and OT-stimulated PG production in epithelial cells provides direct evidence for a cell type-specific modulatory action of cortisol on PG production in stromal cells. Since the endometrium apparently consists of many more stromal cells than epithelial cells, the cortisol-inhibited PGF2 $\alpha$ production by stromal cells could be of physiological relevance inhibiting the initiation of luteolysis.

In conclusion, the overall results suggest that the level of cortisol is locally regulated in non-pregnant bovine endometrium by 11-HSD1, and lead us to hypothesize that cortisol mainly acts as a luteoprotective factor by suppressing luteolytic PGF $2 \alpha$ production in bovine endometrium.

\section{Acknowledgements}

This work was supported by a Grant-in-Aid for Scientific (B) no. 18380166 of the Japan Society for the Promotion of Science (JSPS). H-Y Lee is supported by a scholarship from the Ministry of Education, Culture, Sports, Science and Technology, Japan. We thank Dr S Ito of Kansai Medical University, Osaka, Japan, for antisera of PGF2 $\alpha$ and PGE2, Teikoku Hormone MFG Co. (Tokyo, Japan) for synthetic OT, and Dainippon Pharmaceutical Co. Ltd for recombinant human TNF $\alpha$. The authors declare that there is no conflict of interest that would prejudice the impartiality of this scientific work.

\section{References}

Acosta TJ, Ozawa T, Kobayashi S, Hayashi K, Ohtani M, Kraetzl WD, Sato K, Schams D \& Miyamoto A 2000 Periovulatory changes in the local release of vasoactive peptides, prostaglandin $\mathrm{F} 2 \alpha$, and steroid hormones from bovine mature follicles in vivo. Biology of Reproduction 63 1253-1261.

Acosta TJ, Yoshizawa N, Ohtani M \& Miyamoto A 2002 Local changes in blood flow within the early and midcycle corpus luteum after prostaglandin F2 $\alpha$ injection in the cow. Biology of Reproduction 66 651-658.
Albiston AL, Obeyesekere VR, Smith RE \& Krozowski ZS 1994 Cloning and tissue distribution of the human $11 \beta$-hydroxysteroid dehydrogenase type 2 enzyme. Molecular and Cellular Endocrinology 105 R11-R17.

Alfaidy N, Xiong ZG, Myatt L, Lye SJ, MacDonald JF \& Challis JR 2001 Prostaglandin F2 $\alpha$ potentiates cortisol production by stimulating $11 \beta$-hydroxysteroid dehydrogenase 1: a novel feedback loop that may contribute to human labor. Journal of Clinical Endocrinology and Metabolism 86 5585-5592.

Andersen CY 2002 Possible new mechanism of cortisol action in female reproductive organs: physiological implications of the free hormone hypothesis. Journal of Endocrinology 173 211-217.

Asselin E \& Fortier MA 2000 Detection and regulation of the messenger for a putative bovine endometrial 9-keto-prostaglandin E2 reductase: effect of oxytocin and interferon-tau. Biology of Reproduction 62 125-131.

Asselin E, Bazer FW \& Fortier MA 1997 Recombinant ovine and bovine interferons $\tau$ regulate prostaglandin production and oxytocin response in cultured bovine endometrial cells. Biology of Reproduction 56 402-408.

Bigsby RM \& Everett LM 1991 Effects of progestin antagonists, glucocorticoids and estrogen on progesterone-induced protein secreted by rabbit endometrial stromal cells in culture. Journal of Steroid Biochemistry and Molecular Biology 39 27-32.

Brann DW \& Mahesh VB 1991 Role of corticosteroids in female reproduction. FASEB Journal 5 2691-2698.

Encio IJ \& Detera-Wadleigh SD 1991 The genomic structure of the human glucocorticoid receptor. Journal of Biological Chemistry 266 7182-7188.

Escher G, Galli I, Vishwanath BS, Frey BM \& Frey FJ 1997 Tumor necrosis factor $\alpha$ and interleukin $1 \beta$ enhance the cortisone/cortisol shuttle. Journal of Experimental Medicine 186 189-198.

Fortier MA, Guilbault LA \& Grasso F 1988 Specific properties of epithelial and stromal cells from the endometrium of cows. Journal of Reproduction and Fertility 83 239-248.

Funder JW 1993 Mineralocorticoids, glucocorticoids, receptors and response elements. Science 259 1132-1133.

Gellersen B, Kempf R, Telgmann R \& DiMattia GE 1994 Nonpituitary human prolactin gene transcription is independent of Pit-1 and differentially controlled in lymphocytes and in endometrial stroma. Molecular Endocrinology 8 356-373.

Giguere V, Hollenberg SM, Rosenfeld MG \& Evans RM 1986 Functional domains of the human glucocorticoid receptor. Cell 46 645-652.

Goppelt-Struebe M 1997 Molecular mechanisms involved in the regulation of prostaglandin biosynthesis by glucocorticoids. Biochemical Pharmacology $\mathbf{5 3}$ 1389-1395.

Goppelt-Struebe M, Reiser CO, Schneider N \& Grell M 1996 Modulation of tumor necrosis factor (TNF) receptor expression during monocytic differentiation by glucocorticoids. Inflammation Research 45 503-507.

Gupta S, Gyomorey S, Lye SJ, Gibb W \& Challis JR 2003 Effect of labor on glucocorticoid receptor (GR(Total), GR $\alpha$, and GR $\beta$ ) proteins in ovine intrauterine tissues. Journal of the Society for Gynecologic Investigation $10136-144$.

Hillier SG \& Tetsuka M 1998 An anti-inflammatory role for glucocorticoids in the ovaries? Journal of Reproductive Immunology 39 21-27.

Hollenberg SM, Weinberger C, Ong ES, Cerelli G, Oro A, Lebo R, Thompson EB, Rosenfeld MG \& Evans RM 1985 Primary structure and expression of a functional human glucocorticoid receptor cDNA. Nature 318 635-641.

Hryb DJ, Khan MS, Romas NA \& Rosner W 1990 The control of the interaction of sex hormone-binding globulin with its receptor by steroid hormones. Journal of Biological Chemistry 265 6048-6054.

Korgun ET, Dohr G, Desoye G, Demir R, Kayisli UA \& Hahn T 2003 Expression of insulin, insulin-like growth factor I and glucocorticoid receptor in rat uterus and embryo during decidualization, implantation and organogenesis. Reproduction 125 75-84.

Labarca C \& Paigen K 1980 A simple, rapid, and sensitive DNA assay procedure. Anaytical Biochemistry 102 344-352.

Madore E, Harvey N, Parent J, Chapdelaine P, Arosh JA \& Fortier MA 2003 An aldose reductase with $20 \alpha$-hydroxysteroid dehydrogenase activity is 
most likely the enzyme responsible for the production of prostaglandin F2 $\alpha$ in the bovine endometrium. Journal of Biological Chemistry 278 11205-11212.

Magness RR, Huie JM, Hoyer GL, Huecksteadt TP, Reynolds LP, Seperich GJ, Whysong G \& Weems CW 1981 Effect of chronic ipsilateral or contralateral intrauterine infusion of prostaglandin E2 (PGE2) on luteal function of unilaterally ovariectomized ewes. Prostaglandins and Medicine 6 389-401.

McCann JP \& Hansel W 1986 Relationships between insulin and glucose metabolism and pituitary-ovarian functions in fasted heifers. Biology of Reproduction 34 630-641.

McCracken JA, Custer EE \& Lamsa JC 1999 Luteolysis: a neuroendocrinemediated event. Physiological Reviews 79 263-323.

McKay LI \& Cidlowski JA 1998 Cross-talk between nuclear factor- $\kappa$ B and the steroid hormone receptors: mechanisms of mutual antagonism. Molecular Endocrinology 12 45-56.

McKay LI \& Cidlowski JA 1999 Molecular control of immune/inflammatory responses: interactions between nuclear factor- $\kappa \mathrm{B}$ and steroid receptorsignaling pathways. Endocrine Reviews 20 435-459.

Michael AE, Thurston LM \& Rae MT 2003 Glucocorticoid metabolism and reproduction: a tale of two enzymes. Reproduction 126 425-441.

Miyamoto Y, Skarzynski DJ \& Okuda K 2000 Is tumor necrosis factor $\alpha$ a trigger for the initiation of endometrial prostaglandin F2 $\alpha$ release at luteolysis in cattle? Biology of Reproduction 62 1109-1115.

Monheit AG \& Resnik R 1981 Corticosteroid suppression of estrogeninduced uterine blood flow in nonpregnant sheep. American Journal of Obstetrics and Gynecology 139 454-458.

Munck A, Guyre PM \& Holbrook NJ 1984 Physiological functions of glucocorticoids in stress and their relation to pharmacological actions. Endocrine Reviews 5 25-44.

Murakami S, Miyamoto Y, Skarzynski DJ \& Okuda K 2001 Effects of tumor necrosis factor- $\alpha$ on secretion of prostaglandins $\mathrm{E} 2$ and F2 $\alpha$ in bovine endometrium throughout the estrous cycle. Theriogenology 55 1667-1678.

Murakami S, Shibaya M, Takeuchi K, Skarzynski DJ \& Okuda K 2003 A passage and storage system for isolated bovine endometrial epithelial and stromal cells. Journal of Reproduction and Development 49 531-538.

Oakley RH, Sar M, Cidlowski JA \& Cidlowski JA 1996 The human glucocorticoid receptor $\beta$ isoform. Expression, biochemical properties, and putative function. Journal of Biological Chemistry 271 9550-9559.
Okuda K, Kito S, Sumi N \& Sato K 1988 A study of the central cavity in the bovine corpus luteum. Veterinary Record 123 180-183.

Pratt BR, Butcher RL \& Inskeep EK 1977 Antiluteolytic effect of the conceptus and of PGE2 in ewes. Journal of Animal Science 45 784-791.

Rabin DS, Johnson EO, Brandon DD, Liapi C \& Chrousos GP 1990 Glucocorticoids inhibit estradiol-mediated uterine growth: possible role of the uterine estradiol receptor. Biology of Reproduction 42 74-80.

Sakumoto R, Komatsu T, Kasuya E, Saito T \& Okuda K 2005 Expression of mRNAs for interleukin-4, interleukin-6 and their receptors in porcine corpus luteum during the estrous cycle. Domestic Animal Endocrinology 31 246-257.

Salamonsen LA \& Lathbury LJ 2000 Endometrial leukocytes and menstruation. Human Reproduction Update 6 16-27.

Skarzynski DJ, Miyamoto Y \& Okuda K 2000 Production of prostaglandin F2 $\alpha$ by cultured bovine endometrial cells in response to tumor necrosis factor $\alpha$ : cell type specificity and intracellular mechanisms. Biology of Reproduction 62 1116-1120.

Skarzynski DJ, Bah MM, Deptula KM, Woclawek-Potocka I, Korzekwa A, Shibaya M, Pilawski W \& Okuda K 2003 Role of tumor necrosis factor- $\alpha$ on the estrous cycle in cattle: an in vivo study. Biology of Reproduction 69 1907-1913.

Stewart PM \& Mason JI 1995 Cortisol to cortisone: glucocorticoid to mineralocorticoid. Steroids 60 143-146.

Stewart PM, Murry BA \& Mason JI 1994 Type 2 11ß-hydroxysteroid dehydrogenase in human fetal tissues. Journal of Clinical Endocrinology and Metabolism 78 1529-1532.

Wang M 2005 The role of glucocorticoid action in the pathophysiology of the metabolic syndrome. Nutrition and Metabolism 23.

Woclawek-Potocka I, Deptula K, Bah MM, Lee HY, Okuda K \& Skarzynski DJ 2004 Effects of nitric oxide and tumor necrosis factor- $\alpha$ on production of prostaglandin F2 $\alpha$ and E2 in bovine endometrial cells. Journal of Reproduction and Development $50333-340$.

Received in final form 25 December 2006

Accepted 23 January 2007

Made available online as an Accepted Preprint 24 January 2007 